\title{
Transference of microsatellite markers from Eucalyptus spp to Acca sellowiana and the successful use of this technique in genetic characterization
}

\author{
Karine Louise dos Santos ${ }^{1}$, Leocir José Welter ${ }^{1}$, Adriana Cibele de Mesquita Dantas ${ }^{1}$, \\ Miguel Pedro Guerra ${ }^{1}$, Jean Pierre Henri Joseph Ducroquet ${ }^{2}$ and Rubens Onofre Nodari ${ }^{1}$ \\ ${ }^{1}$ Laboratório de Fisiologia do Desenvolvimento e Genética Vegetal, Departamento de Fitotecnia, \\ Centro de Ciências Agrárias, Universidade Federal de Santa Catarina, Florianópolis, SC, Brazil. \\ ${ }^{2}$ Estação Experimental de São Joaquim, Epagri, São Joaquim, SC, Brazil.
}

\begin{abstract}
The pineapple guava (Acca sellowiana), known in portuguese as the goiabeira-serrana or "Feijoa", is a native fruit tree from southern Brazil and northern Uruguay that has commercial potential due to the quality and unique flavor of its fruits. Knowledge of genetic variability is an important tool in various steps of a breeding program, which can be facilitated by the use of molecular markers. The conservation of repeated sequences among related species permits the transferability of microsatellite markers from Eucalyptus spp. to A. sellowiana for testing. We used primers developed for Eucalyptus to characterize A. sellowiana accessions. Out of 404 primers tested, 180 amplified visible products and 38 were polymorphic. A total of 48 alleles were detected with ten Eucalyptus primer pairs against DNA from 119 A. sellowiana accessions. The mean expected heterozygosity among accessions was 0.64 and the mean observed heterozygosity 0.55 . A high level of genetic diversity was also observed in the dendrogram, where the degree of genetic dissimilarity ranged from 0 to $65 \%$ among the 119 genotypes tested. This study demonstrates the possibility of transferring microsatellite markers between species of different genera in addition to evaluating the extent of genetic variability among plant accessions.
\end{abstract}

Keywords: Feijoa sellowiana, genetic diversity, goiabeira-serrana, pineapple-guava, transferability.

Received: January 17, 2006; Accepted: July 21, 2006.

\section{Introduction}

The pineapple guava (Acca sellowiana, synonym Feijoa sellowiana), known in portuguese as the goiabeiraserrana or "Feijoa", is a native of the Brazilian southern plateau with secondary dispersion in Uruguay (Mattos, 1990; Thorp and Bieleski, 2002). Due to the uniqueness of its flavor, the economic importance of the pineapple guava is steadily increasing on the world market (Thorp and Bieleski, 2002) and it is an attractive commercial alternative for farmers in southern Brazil (Mattos, 1990).

Although the pineapple guava can be found on the European market or in the countries in which adapted cultivars are active (e.g. New Zealand, Colombia and the USA) as yet there are no improved cultivars in Brazil, its greatest center of diversity. However, there is an $A$. sellowiana Active Germplasm Bank (AGB) located at the

Send correspondence to Karine Louise dos Santos. Departamento de Fitotecnia, Centro de Ciências Agrárias, Universidade Federal de Santa Catarina, Caixa Postal 476, 88040-900 Florianópolis, SC, Brazil. E-mail: karinesantos@cca.ufsc.br.
São Joaquim Experimental Station (Estação Experimental de São Joaquim (EPAGRI), São Joaquim-SC, Brazil) in the town of São Joaquim in the Brazilian state of Santa Catarina. This germplasm bank contains 119 A. sellowiana accessions from several regions of Brazil and other countries, and it is possible to use directly an accession as a clone or to develop a cultivar by means of genetic breeding methods in order to scale up commercial production

The genetic variability of this species is normally high at the center of origin, and information on such variability is essential for A. sellowiana conservation, breeding and commercial production. In general, specific phenotypes of discreet variation are used as morphological markers. However, a limited number of morphological markers have been identified for this species (Nodari et al., 1997), which are frequently affected by dominance and epistatic gene interactions, environmental effects and pleiotropy. To overcome such problems, molecular markers can be used to help genetic characterization and breeding (Nodari et al., 1997; Brondani et al., 1998, 1997). 
Among the classes of molecular markers available to identify variation at DNA level, the microsatellites, or simple sequence repeats (SSRs), are considered ideal markers for genetic studies because they combine several suitable features: (i) co-dominance; (ii) multiallelism; (iii) high polymorphism, allowing precise discrimination even of closely related individuals; (iv) abundance and uniform dispersion in plant genomes; and (v) the possibility of efficient analysis by a rapid and simple polymerase chain reaction (PCR) assay (Morgante and Olivieri, 1993; Rafalski and Tingey, 1993; Sharma et al., 1995; Brondani et al., 1998). In addition, for the amplification of microsatellite loci, a knowledge of their DNA sequence is required, and this is an expensive and time consuming process (Zucchi et al., 2003). However, the approach of using enriched libraries with repetitive sequences has been very successful in developing SSRs at a reasonable cost (Zane et al., 2002).

The ability to use the same microsatellite primers in different plant species, called transferability, depends on the extent of sequence conservation in the primer sites flanking the microsatellite loci and the stability of those sequences during evolution (Choumane et al., 2000; Decroocq et al., 2003; Zucchi et al., 2003). It has been shown that closely related species are more likely to share microsatellite priming sites than more distantly related ones, but it is possible to transfer functional microsatellite primers even from more distantly related species (Lorieux et al., 2000).

Because there are no microsatellites available for $A$. sellowiana, the Eucalyptus spp. primers of microsatellite loci (Brondani et al., 1998) can be used as an alternative to find similar regions on the $A$. sellowiana genome, since they belong to the same family (Zucchi et al., 2003).

Thus, the objectives of the work described in this paper were to evaluate the transferability of microsatellite markers from Eucalyptus to A. sellowiana (both members of the Myrtaceae) and to characterize the genetic variability present in the Active Germplasm Bank (AGB) of this species.

\section{Material and Methods}

\section{Genetic material}

The 119 accessions tested shown in Table 1 were obtained from the pineapple guava Active Germplasm Bank (AGB) located at the São Joaquim Experimental Station (Estação Experimental de São Joaquim - EPAGRI, São Joaquim-SC, Brazil). Most of the accessions came from the Brazilian state of Santa Catarina, although a few accessions came from other countries (Table 1).Samples of DNA were obtained following the protocol developed by Doyle and Doyle (1987). The extracted DNA was quantified in agarose gel (Sambrook et al., 1989) and diluted to $3 \mathrm{ng} \mu \mathrm{L}^{-1}$ for further use in the amplification reactions. Leaf DNA from Eucalyptus grandis was used as a control.

\section{Microsatellite markers and DNA isolation}

For amplification in A. sellowiana we used 404 primer pairs developed by Brondani et al. (1998) for the Eucalyptus complex E. grandis x E. Urophylla and they were obtained from the Genetics and Biotechnology unit of the Brazilian agricultural company Embrapa (Empresa Brasileira de Pesquisa Agropecuária-Recursos Genéticos e Bio-

Table 1 - Accession number and origin of the 119 accessions from the Active Germoplasm Bank of Goiabeira-serrana located at the São Joaquim/Epagri Experimental Station in the Brazilian state of Santa Catarina. All the Brazilian cities are located in the state of Santa Catarina.

\begin{tabular}{|c|c|c|c|}
\hline \multicolumn{4}{|c|}{ Country, city of isolation and accession number } \\
\hline \multicolumn{3}{|l|}{ Brazil } & \multirow{2}{*}{$\begin{array}{l}\text { Other counties } \\
\text { Israel: } 459, \text { Israel }^{*}\end{array}$} \\
\hline $\begin{array}{l}\text { Bom Jardim: } 370,371,372,373 \text {, } \\
\text { 373B, 374, 376, } 527\end{array}$ & $\begin{array}{l}\text { Lages: } 228,229,246,247,249, \\
250,259,276,276 \mathrm{~B}, 276-20 \mathrm{~A}, 27 \\
8-1,278-2,294,301,306 \mathrm{~B}, 321,3 \\
26 \mathrm{~B}, 331,332,337,401\end{array}$ & $\begin{array}{l}\text { Urupema: } 233,234,238,239-2 \text {, } \\
240,242,244,390,392\end{array}$ & \\
\hline Caçador: $66,511,512,522$ & Palmas: $159-27,159-30$ & Vacaria: 902,903 & $\begin{array}{l}\text { New Zealand: 451, 454, 456, 457, } \\
\text { 457A, 457B }\end{array}$ \\
\hline Campos Novos: 85 & Papanduvas: 755 & Vargem Bonita: 804, 805, 805-2 & Unknown origin: 438 \\
\hline Curitibanos: 80, 735A, 735B, 735 & Ponte Alta152-24, 732, 732B, 740 & & Uruguai: 441 \\
\hline Frei Rogério: 79 & $\begin{array}{l}\text { São Joaquim: } \\
\text { 103, 110,117, 118, 119, 120, 124, } \\
260,277,300,358,359,360,366 \text {, } \\
369,387\end{array}$ & $\begin{array}{l}\text { Videira: 50, 50-2, 53, 53B } 7 \\
\text { 59-30, 91, 98A, 98B, 101, 101PR, } \\
\text { 132, 135, 152-12, 333, 393, 509, } \\
526,528\end{array}$ & USA: 452-Califórnia, 453-USA \\
\hline $\begin{array}{l}\text { Fraiburgo: } 148,501,502 B, 504, \\
519,521\end{array}$ & Tangará: 141 & & \\
\hline \multicolumn{4}{|l|}{ Iomerê:150B } \\
\hline Lebon Régis: $138,707,711,712,7$ & & & \\
\hline
\end{tabular}

\footnotetext{
*Unspecified source.
} 
tecnologia, Brasilia, DF, Brazil). Polymerase chain reaction $(\mathrm{PCR})$ amplification of the microsatellite markers was performed in 96-well plates containing a $13 \mu \mathrm{L}$ reaction volume composed of buffer $(10 \mathrm{mM}$ Tris- $\mathrm{HCl} \mathrm{pH} \mathrm{8.3,}$ $50 \mathrm{mM} \mathrm{KCl}, 1.5 \mathrm{mM} \mathrm{MgCl} 2$ ), 5\% (w/v) dimethyl sulfoxide, $9 \mathrm{ng}$ of template DNA, $0.3 \mu \mathrm{M}$ of each primer, $0.02 \mathrm{mM}$ of each dNTP (Invitrogen) and one unit of Taq DNA polymerase (Invitrogen). Amplifications were performed using an MJ Research PT-100 thermal controller adjusted to the following conditions: $96^{\circ} \mathrm{C}$ for $2 \mathrm{~min}$, then 30 cycles of $94^{\circ} \mathrm{C}$ for $1 \mathrm{~min}, 56^{\circ} \mathrm{C}$ for $1 \mathrm{~min}$ and $72^{\circ} \mathrm{C}$ for $1 \mathrm{~min}$ followed by a final elongation step at $72^{\circ} \mathrm{C}$ for $7 \mathrm{~min}$.

The screening of the pairs of primers was done in two steps. The first step employed the DNA of two $A$. sellowiana plants and one control $E$. grandis plant, the amplification products being visualized on $1.5 \%(\mathrm{w} / \mathrm{v})$ agarose gel. In the second step, the pairs of primers showing positive amplification were confronted with an additional group of eight $A$. sellowiana genotypes to detect polymorphism and 10 selected primers were then utilized to analyze the genetic variability in the 119 A. sellowiana accessions, the amplification products being separated on $6 \%(\mathrm{w} / \mathrm{v}) \mathrm{de}-$ naturing polyacrylamide gel. A 100 bp DNA ladder was used as a molecular weight reference to estimate the sizes of the amplification products. The gels were stained with silver nitrate, as described by Creste et al. (2001).

\section{Data analysis}

The genetic diversity characterization potential of the primers was based on allele frequency estimates of the mean observed heterozygosity (Ho), mean expected heterozygosity (He) (Nei, 1978) and the number of alleles per locus for the AGB accessions. These estimates were obtained using the BIOSYS-1 program (Swofford and Selander, 1989). In addition, a dendrogram was plotted from an unbiased genetic similarity matrix (Nei, 1978) grouped by the unweighted pair group method with arithmetic mean (UPGMA) of Sneath and Sokal (1973).

\section{Results}

Of the 404 primer pairs tested we found that 180 (44.5\%) amplified visible products in A. sellowiana. Furthermore, $38(9.4 \%)$ primer pairs allowed the detection of clear bands and easy fragment recognition for eight $A$. sellowiana genotypes, generating an average of 1.5 alleles per locus. Satisfactory amplification products were obtained using an annealing temperature of $56^{\circ} \mathrm{C}$.

When we screened the 119 accessions with ten selected polymorphic primer pairs we detected 49 alleles, varying from $120 \mathrm{bp}$ to $320 \mathrm{bp}$. The quality of the amplification products is shown in Figure 1.

The number of detected alleles per locus ranged from 2 to 9 , averaging 4.9 alleles per locus, with the EMBRA 26 marker being the most polymorphic one (Table 2). The ten

Table 2 - Sequence of the 10 used pairs of primers developed for Eucalyptus genera, allele size range, number of alleles per locus (A), observed heterozygosity $\left(\mathrm{H}_{\mathrm{o}}\right)$ and expected heterozygosity $\left(\mathrm{H}_{\mathrm{e}}\right)$ of amplified microsatellite loci in Acca sellowiana.

\begin{tabular}{|c|c|c|c|c|c|}
\hline Primer* & Sequence (F- forward/ R- Reverse) & Allele size range (bp) & A & $\mathrm{H}_{\mathrm{o}}$ & $\mathrm{H}_{\mathrm{e}}$ \\
\hline EMBRA 26 & $\begin{array}{l}\text { F-CAT GAG TTA CTG CAA GAA AAG } \\
\text { R- ACA GCC AAA AAC CAA ATC }\end{array}$ & $155-320$ & 9 & 0.600 & 0.868 \\
\hline EMBRA 69 & $\begin{array}{l}\text { F-TGT GTT CTC GGT TTC AAA ACT } \\
\text { R- TGT GAA GTG ATG CGA AGC }\end{array}$ & $200-290$ & 5 & 0.434 & 0.758 \\
\hline EMBRA 85 & $\begin{array}{l}\text { F- CAC CTC TCC AAA CTA CAC AA } \\
\text { R- CTC CTC TCT CTT CAC CAT TC }\end{array}$ & $140-300$ & 7 & 0.685 & 0.831 \\
\hline EMBRA 99 & $\begin{array}{l}\text { F- AAT ACA ATT GAG GGG TCT C } \\
\text { R- ACC AAA AAC AAA TGT CGT }\end{array}$ & $230-250$ & 3 & 0.120 & 0.499 \\
\hline EMBRA 108 & $\begin{array}{l}\text { F- CGG TTA CTT GCT TCA TTC G } \\
\text { R- GTA CGG ATG GGT GGA CAC }\end{array}$ & $150-160$ & 2 & 0.505 & 0.442 \\
\hline EMBRA 123 & $\begin{array}{l}\text { F- AGA ACC CTC TAT AAA ACC CC } \\
\text { R- GGG CTA GAC ATG ATG GAG }\end{array}$ & $180-300$ & 5 & 0.813 & 0.656 \\
\hline EMBRA 148 & $\begin{array}{l}\text { F- TGG ATG CTG TTC TCA TCC T } \\
\text { R- GGG TTT CTT TGT GAA ACG A }\end{array}$ & $200-320$ & 6 & 0.702 & 0.695 \\
\hline EMBRA 166 & $\begin{array}{l}\text { F- CTG GTC AAC GTC CGA AAG } \\
\text { R- ATG CTG CAG AGG GCA TAA }\end{array}$ & $130-300$ & 5 & 0.781 & 0.724 \\
\hline EMBRA 265 & $\begin{array}{l}\text { F- TAT CAC TGG CAG GAC GCA } \\
\text { R- ACC GAC GCC GAT AAG AGA }\end{array}$ & $200-250$ & 5 & 0.602 & 0.652 \\
\hline EMBRA 267 & $\begin{array}{l}\text { F- GAC CTC CGC TTC AAC GAT } \\
\text { R- GTG CGA GAC CCT CAA TTC TA }\end{array}$ & $120-140$ & 2 & 0.274 & 0.275 \\
\hline Average & - & - & 4.9 & 0.551 & 0.640 \\
\hline
\end{tabular}

*The primers were those reported by Brondani et al. (1998) and were obtained from the Genetics and Biotechnology unit of the Brazilian agricultural company Embrapa (Empresa Brasileira de Pesquisa Agropecuária-Recursos Genéticos e Biotecnologia, Brasilia, DF, Brazil). 


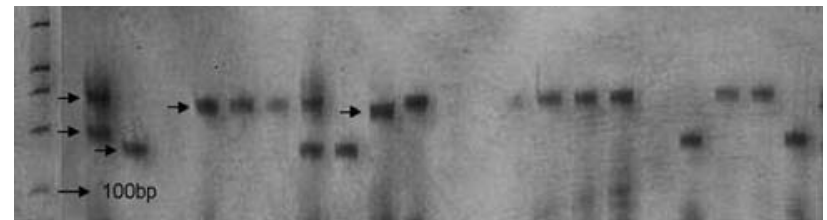

Figure 1 - Profile of the PCR products of 21 Acca sellowiana accessions from the Active Germoplasm Bank. The products were amplified by the Eucalyptus primer EMBRAPA 123 and resolved on silver stained polyacrylamide gel. Left line: $1 \mathrm{~kb}$ Plus DNA Ladder (Invitrogen).

Table 3 - Origin of the plant accessions presenting alleles with a low frequency ( $\mathrm{f}<0.05$ ). All Brazilian cities are located in the state of Santa Catarina.

\begin{tabular}{llll}
\hline $\begin{array}{l}\text { Local } \\
\text { Brazil }\end{array}$ & Primer* & $\begin{array}{l}\text { Local } \\
\text { Brazil (cont) }\end{array}$ & Primer* \\
\hline Bom Jardim & & Ponte Alta & \\
527 & EMBRA 26 & 740 & EMBRA 26 \\
372 & EMBRA 123 & 732 & EMBRA 26 \\
& & 152 & EMBRA 108
\end{tabular}

\section{Caçador}

EMBRA 26

São Joaquim

522

EMBRA 69

103-110

EMBRA 26

511

EMBRA 123

119-120

EMBRA 85

277

EMBRA 108

Campos Novos

85

Curitibanos

735

Fraiburgo

521

501

501-502

EMBRA 26

Vargem Bonita

805

EMBRA 69

805

EMBRA 123

EMBRA 26

Videira

101

EMBRA 26

$101-333$

EMBRA 69

50-91-526

50

EMBRA 85

EMBRA 108

Lages

246-247

229

EMBRA 26

Other countries

276

EMBRA 26

Israel,

Unspecified

EMBRA 26

$$
\text { source }
$$

EMBRA 69 Unspecified

EMBRA 108

$$
\text { source }
$$

250-276

326

246-249

332

EMBRA 85

EMBRA 108

EMBRA 123

New Zealand

456-457

EMBRA 108

Unknown origin

438

EMBRA 85

*The primers were those reported by Brondani et al. (1998) and were obtained from the Genetics and Biotechnology unit of the Brazilian agricultural company Embrapa (Empresa Brasileira de Pesquisa de Agropecuária-Recursos Genéticos e Biotecnologia, Brasilia, DF, Brazil). Local: Country, city of origin and accession number.

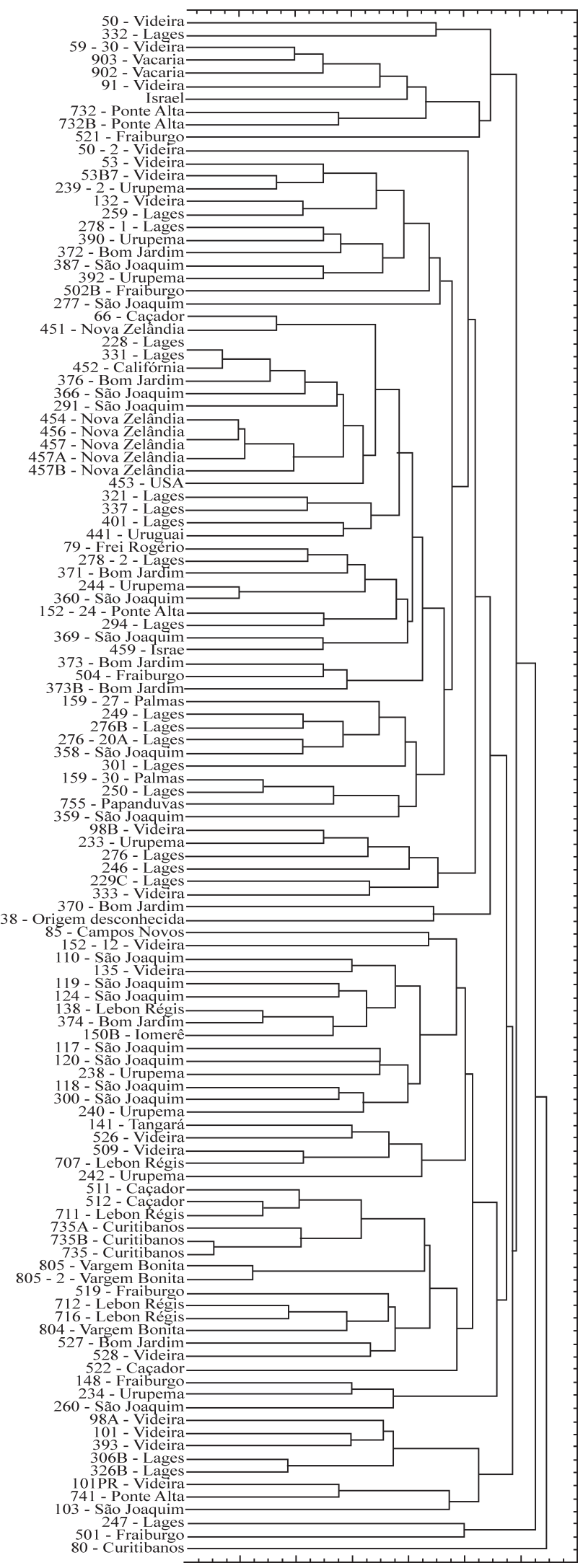

Figure 2 - Unweighted pair group method with arithmetic mean (UPGMA) dendrogram reflecting the genetic similarities, based on 10 microsatellite loci, among 119 accessions from the Acca sellowiana Active Germplasm Bank. 
pairs of primers used were able to detect low frequency alleles $(\leq 0.05)$, which were distributed in accessions of different origins (Table 3 ).

The mean expected heterozygosity among loci was $\mathrm{He}=0.640$, while the mean observed heterozygosity was $\mathrm{Ho}=0.551$ (Table 2). In the dendrogram (Figure 2), the 119 accessions were distributed in different groups and the degree of genetic similarity ranged from $35 \%$ to $100 \%$. Two sub-groups contained two accessions with $100 \%$ similarity, one sub-group consisting of accessions 228 and 331 from Lages and the other sub-group consisting of the New Zealand accessions 456 and 457. On the other hand, three accessions formed two sub-groups, one of which contained accession 80 from Curitibanos (37.5\% similarity with the other 117 accessions) and the other accession 247 from Lages plus accession 501 from Fraiburgo (35\% similarity with the other 117 accessions), these two sub groups being very different from the other sub-groups. Besides this main feature of grouping, the other sub-groups did not reveal any special structure, except one, which included 7 out of 9 accessions from outside Brazil. Interestingly, the two genotypes from Israel were located outside the group that included accessions from the USA, New Zealand and Brazil.

\section{Discussion}

Considering the time-consuming and expensive process of microsatellites isolation (Powell et al., 1996), we took advantage of the availability of Eucalyptus primer sequences and used them in Acca sellowiana. Our study demonstrated the transferability of microsatellite markers from Eucalyptus to Acca across different genera belonging to the same family (Myrtaceae). This demonstration of transferability means that future genetic studies can be carried out, this marker type being extremely useful due to its ease of use and high amount of information generated. Because of these features, microsatellites are considered as useful molecular markers in plant breeding, and are widely used for cultivar fingerprinting, paternity testing and genome mapping.

The transferability across related species and genera makes these markers very powerful for comparative genetic studies (Szewc-Mcfadden et al., 1996; Smulders et al., 1997 Roa et al., 2000). A high cross-species conservation of microsatellite loci within genera has been reported in tree species such as Citrus (Kijas et al., 1995), Prunus (Cipriani et al., 1999; Dirlewanger et al., 2002; Wünsh and Hormaza, 2002), Elaieis (Billote et al., 2001), Picea (Hodgetts et al., 2001), Pinus (Shepherd et al., 2002; Liewlaksaneeyanawin et al., 2004), Olea (Olive) (Sefc et al., 2000), Malus (Coart et al., 2003) and Eucalyptus (Marques et al., 2002).

However, a cautious approach is required when comparing similar PCR products obtained across different species, since various factors can cause size homoplasy. Over long periods of evolution, the interspecific allelic differences at one locus are often more complex than simple changes in repeat number. Products amplified in different species might include mutation, rearrangements and duplications in the flanking region and/or changes in the number of repeats (Peakall et al., 1998).

Microsatellite transferability has also been confirmed to occur between species from different genera. In the work described in this paper we have demonstrated that primer pairs developed for Eucalyptus were able to amplify in the A. sellowiana genome. Zucchi et al. (2003) used a sample from the same set of Eucalyptus complex primer pairs to test their transferability to other Myrtaceae species such as Eugenia dysenteria and found that of the 356 microsatellite primer pairs tested it was possible to transfer 10, representing a transferability of $2.8 \%$. Interestingly, none of the microsatellite primer pairs transferred to Eugenia dysenteria by Zucchi et al. (2003) coincided with the primers transferred to A. sellowiana in our study. Although it is premature to make inferences about relatedness before obtaining further evidence, by considering these results together it can be hypothesized that there is more similarity between Acca and Eucalyptus than between Eugenia and Eucalyptus. According to Palop et al. (2000), microsatellites loci are more likely to be amplified in closely related species.

The number of primer pairs transferred from Eucalyptus to A. sellowiana (44.5\%) can be considered very high in comparison to other studies (Padian et al., 2000). In addition, at least $26 \%$ of the primer pairs transferred were able to detect polymorphism among the 119 A. sellowiana genotypes screened, which can be considered to be a high level in light of the fact that in the study by Zucchi et al. (2003) cited above with 10 pairs of Eucalyptus primers transferred to E. dysenteria the level of polymorphism was only $2 \%$.

It is relevant to mention the existence of a large amount of genetic variability among the $A$. sellowiana accessions. Besides supporting such a conclusion, the presence of alleles with a low frequency in accessions of different origins suggests that the genetic variability is dispersed across locations. Genotypes with a low level of similarity in comparison with others were also found in this study. This high amount of genetic variability is no surprise, since the $A$. sellowiana germplasm bank contains a collection of 119 representatives from 14 locations distributed across southern Brazil. Most of the accessions have agronomic importance, since they express one or more agronomic traits that can be further integrated into breeding programs.

The high value of expected heterozygosity in comparison with observed heterozygosity among the accessions in the A. sellowiana germplasm bank indicates that heterozygote deficit is present in the germplasm bank accessions. However, this deficit is relatively low and the heterozy- 
gosity is high, which suggests the existence of high genetic diversity in the natural populations from which the $A$. sellowiana accessions were collected.

The dendrogram which we obtained based on 10 loci showed two sub-groups consisting of two accessions each, with $100 \%$ of similarity. At the other extreme, three accessions showed a low degree of similarity (from 35.0 to $37.5 \%$ ) with the other 117 plant accessions. These results agree with the high values of heterozygosity and the 48 alleles detected in the Active Germplasm Bank. It is important to mention that the accessions from New Zealand and the United States were included in a sub-group, indicating the narrowing of the genetic base for these accessions and a substantial degree of relationship among them.

This study has demonstrated the transferability of $E u-$ calyptus spp. microsatellite markers to Acca sellowiana, which belong to the same family (Myrtaceae) but are distinct genera. Because the Eucalyptus microsatellite loci were able to detect the existence of a large amount of genetic variability among the $A$. sellowiana accessions they can be used for genetic characterization of both accessions and natural populations, knowledge of which helps to accelerate not only the establishment of appropriate conservation strategies but also marker assisted selection, the selection of parents for controlled crosses and the monitoring of the segregation of genomic regions of agronomic interest in segregating progenies. In addition, the Eucalyptus primers can be used for genetic studies in other Myrtaceae species for which there are no species-specific microsatellites available.

\section{Acknowledgments}

The authors thank Embrapa Recursos Genéticos e Biotecnologia for the primer sequences and the Brazilian agencies CNPq and PRODETAB for a research grant. The Brazilian agency CAPES provided scholarships to KLS and ACMD.

\section{References}

Billote N, Risterucci AM, Barcelos E, Noyer JL, Amblard P and Baurens FC (2001) Development, characterization and across-taxa utility of oil palm (Elaeis guineensis Jacq) microsatellites markers. Genome 44:413-425.

Brondani RPV, Brondani C, Tarchini R and Grattapaglia D (1998) Development, characterization and mapping of microsatellite markers in Eucalyptus grandis and E. urophylla. Theor Appl Genet 97:816-827.

Cipriane G, Lot G, Huang WG, Marrazzo MT, Peterlunger E and Testolin R (1999) AC;GT and AG;CT microsatellite repeats in peach (Prunus persica (L) Batsch): Isolation, characterization and cross-species amplification in prunus. Theor Appl Genet 99:65-72.

Choumane W, Winter P, Weigand F and Kahl G (2000) Conservation and variability of sequence-tagged microsatellite sites (STMSs) from chickpea (Cicer aerietinum L.) within the genera Cicer. Theor Appl Genet 101:269-278.
Coart E, Vekemans X, Smulders MJM, Wagner I, Huylenbroeck JV, Bockstaele EV and Roldán-Ruiz I (2003) Genetic variation in the endangered will apple (Malus sylvestris) in Belgium as revealed by amplified fragment length polymorphism and microsatellite markers. Mol Ecol $12: 845-857$

Creste S, Tulmann-Neto A and Figueira A (2001) Detection of single sequence repeat polymorphism in denaturing polyacrylamide sequencing gels by silver staining. Plant Mol Biol Reptr 19:1-8.

Decroocq V, Fave MG, Hagen L, Bordenave L and Decroocq S (2003) Development and transferability of apricot and grape EST microsatellite markers across taxa. Theor Appl Genet 106:912-922.

Dirlewanger E, Cosson P, Tavaud M, Aranzana MJ, Poizat C, Zanetto A, Arus P and Laigret F (2002) Development of microsatellite markers in peach (Prunus persica (L) Batsch) and their use in genetic diversity analysis in peach and sweet cherry (Prunus avium L). Theor Appl Genet 105:127-138.

Doyle JJ and Doyle JL (1987) Isolation of plant DNA from fresh tissue. Focus 12:13-15.

Hodgetts RB, Aleksiuk MA, Brown A, Clarke C, Macdonald E, Nadeem S and Khasa D (2001) Development of microsatellite markers for white spruce (Picea glauca) and related species. Theor Appl Genet 102:1252-1258.

Hokanson SC, Szewc-Mcfadden AK, Lamboy WF and Mcferson JR (1998) Microsatellite (SSR) markers reveal genetic identities, genetic diversity and relationships in a Malus $x$ domestica Borkh. Core subset collection. Theor Appl Genet 97:671-683.

Kijas JMH, Fowler JCS and Thomas MR (1995) An evaluation of sequence tagged microsatellite site markers for genetic analysis within Citrus and related species. Genome 38:349-355.

Liewlaksaneeyanawin C, Ritland CE, El-Kassaby YA and Ritland K (2004) Single-copy, species-transferable microsatellite markers developed from loblolly pine ESTs. Theor Appl Genet 109:361-369.

Lorieux M, Ndjiondjop M-N and Ghesquière A (2000) A first interspecific Oryza sativa \& Oryza glaberrima microsatellite-based genetic linkage map. Theor Appl Genet 100:593601.

Marques CM, Brondani RPV, Grattapaglia D and Sederoff R (2002) Conservation and synteny of SSR loci and QTLs for vegetative propagation in four Eucalyptus species Theor Appl Genet 105:474-478.

Mattos JR (1990) Goiabeira Serrana Fruteiras Nativas do Brasil. $2^{\circ}$ edição. Gráfica Ceue, Porto Alegre, 120 pp.

Morgante M and Olivieri AM (1993) Hypervariable microsatellites in plants. Plant J 3:175-182.

Nei, M (1978) Estimation of averageheterozigosity and genetic distance from a small number of individuals. Genetics 89:583-590

Nodari RO, Ducroquet JP, Guerra MP and Meler K (1997) Genetic variability of Feijoa sellowiana germplasm. Acta Hort 452:41-46.

Pandian A, Ford R and Taylor PWJ (2000) Transferability of Sequence Tagged Microsatellite Site (STMS) primers across four major pulses. Plant Mol Biol Reptr 18:395-395.

Palop M, Palacios C and Gonzáles-Candelas F (2000) Development and across-species transferability of microsatellite 
markers in the genera Limonium (Plumbaginaceae). Conserv Genet 1:177-179.

Peakall R, Gilmore S, Keys W, Morgante M and Rafalski A (1998) Cross species amplification of Soybean (Glycine max) simple-sequence-repeats (SSRs) within the genera and other legume genera: Implications for the transferability of SSRs in plants. Mol Biol Evol 15:1275-1287.

Powell W, Machray GC and Provan J (1996) Polymorphism revealed by simple sequence repeats. Trends Plant Sci 1:215222.

Rafalski JA and Tingey SV (1993) Genetic diagnostics in plant breeding: RAPD's, microsatellites and machines. Theor Appl Genet 8:275-280.

Roa AC, Chavarriaga-Aguirre P, Duque MC, Maya MM, Bonierbale MW, Iglesias C and Thome J (2000) Cross species amplification of cassava (Manhihot esculenta) (Eurphorbiaceae) microsatellites: Allelic polymorphism and degree of relationship. Amer J Bot 87:1647-1655.

Sambrook J, Fritsch EF and Maniatis T (1989) Molecular Cloning: A Laboratory Manual. 2nd edition. Cold Spring Harbor Laboratory Press, New York.

Sefc KM, Lopes MS, Mendonça D, Rodrigues Dos Santos M, Laimer Da Câmara Machado M and Da Câmara Machado A (2000) Identification of microsatellites loci in olive (Olea europaea) and their characterization in Italian and Iberian olive trees. Mol Ecol 9:1171-1173.

Sharma PC, Winter P, Bünger T, Hüttel B, Weingand F, Weising $\mathrm{K}$ and Kahl G (1995) Abundance and polymorphism of di, tri and tetranucleotide tandem repeats in chickpea (Cicer arietinum L.). Theor Appl Genet 90:90-96.
Shepherd M, Cross M, Maguire TL, Dieters MJ, Williams CG and Henry RJ (2002) Transpecific microsatellites for hard pines. Theor Appl Genet 104:819-827.

Smulders MJM, Bredemeijer G, Rus-Kortekaas W, Arens P and Vosman B (1997) Use of short microsatellites to generate polymorphisms among Lycopersicon esculentum cultivars and accessions of other Lycopersicon species. Theor Appl Genet 94:264-272.

Sneath PHA and Sokal RR (1973). Numeral Taxonomy. The Principles and Practice of Numerical Classification. W.H. Freeman, San Francisco, 573 pp.

Swofford DL and Selander RBA (1989) A computer program for the analysis of allelic variation in population genetics and biochemical systematics. Release 1.7. Natural History Survey, Illinois, $43 \mathrm{pp}$.

Szewc-McFadden AK, Kresovich S, Bliek SM, Mitchell SE and McFerson JR (1996) Identification of polymorphic, conserved simple sequence repeats (SSRs) in cultivated Brassica species. Theor Appl Genet 93:534-538.

Thorp G and Bieleski R (2002) Feijoas: Origins, Cultivation and Uses. HortResearch, Ed. David Bateman, 87 pp.

Wünsch A and Hormaza JI (2002) Molecular characterization of sweet cherry (Prunus avium L) genotypes using peach (Prunus persica (L) Batsch) SSR sequences. Heredity 89:56-63.

Zane L, Bargelloni L and Patanello T (2002) Strategies for microsatellite isolation: A review. Mol Ecol 11:1-16.

Zucchi MI, Brondani RPV, Pinheiro JB, Chaves LJ, Coelho ASG and Vencovsky R (2003) Genetic structure and gene flow in Eugenia dysenterica DC in the Brazilian Cerrado utilizing SSR markers. Genet Mol Biol 26:449-457. Associate Editor: Márcio de Castro Silva Filho 